\title{
DETECTION OF TILMICOSIN RESIDUE IN MUSCLES, LIVER AND KIDNEY OF BROILERS AND ITS EFFECT ON LIVER, KIDNEY FUNCTION AND IMMUNITY
}

\author{
SEHAM N. HOMOUDA; AML M. RAGAB; SOAD S. BELIH and AML F.ZOGHBI \\ Animal Health Research Institute, Tanta \\ Email: dr-m-wagdy@hotmail.com
}

\section{ABSTRACT}

Received at: $28 / 12 / 2013$

One hundred one day day old broiler chickens were fed balanced rations ad libitum with free access to water. At 3 weeks in this study. 10 birds as a random samples were scarified for postmortem and bacteriological examination to detect Pasteurella and to serum plate agglutination test (SPA) to prove that free

Accepted: 20/2/2014 from Mycoplasma gallisipticum. Other birds were randomly divided into three groups of 30 chickens each. The first group was a control. The second and third groups administered tilmicosin in drinking water at concentrations of 30 and 60 $\mathrm{mg} / \mathrm{kg}$ bw for 5 days. Six chickens of each group, three males and three females, were slaughtered on days 3, 7,14 and 21 days after dosing. The results reveled significant increase in lymphocytes transformation test (LTT) in high dose administration of tilimicosin at the end of experiment. High dose of tilmicosin $(\mathrm{H} 1, \mathrm{H} 2)$ caused decrease albumin levels and $\mathrm{y}$ globulin. The result revealed no significant changes in serum creatinine in all period of experiment. Alanine amino transferrase (ALT) showed significant increase in groups treated with low and high dose in all period of experiment. Aspartate amino transeferrase (AST) showed non significant changes on group treated with low dose but high dose treated group revealed significant increase in $1^{\text {st }}$ and $2^{\text {nd }}$ periods only and return to normal level in the $3^{\text {rd }}$ period. Serum alkaline phosphatase (ALP) revealed significant increase in group treated with high dose in all period of experiment. The residue levels in both doses were significantly higher in liver than kidney or muscle at 3, 7,14 day post treatment and not detected at 21 day post treatment in all examined samples including liver. The results indicated that tilmicosin residue was eliminated from muscle very quickly, but from liver very slowly. The minimum withdrawal time of 7 days for low dose and 14 days for high dose. The chromatograms obtained with this method was validated with limit of tilmicosin detection $10 \mu \mathrm{g} / \mathrm{kg}$.

Key words: Tilmicosin residue, Broilers, Immunity.

\section{INTRODUCTION}

The way of use of antibiotics in veterinary medicine is very important for the animal health security. Also, it is important for the food safety and the public health as well (Gary Butcher, 2006). Many times the use of antibiotics is out of control, which can cause some residues at the chicken meat and problems to public health.Tilmicosin is a semisynthetic macrolide antibiotic with a wide range of veterinary uses for the treatment of bacterial and mycoplasma infections. Tilmicosin is composed of cis- and trans-pyrimidinyl isomers in a ratio of about 85:15. Tilmicosin has a spectrum of antimicrobial activity that includes Pasteurella spp., Mycoplasma spp., and a variety of Gram-positive organisms (Ose, 1987). Tilmicosin has a stronger antimicrobial activity than tylosin against Pasteurella haemolytica, Pasteurella multocida, and Mycoplasma (Inamoto,
1994 and Stephens et al., 1993). Tilmicosin has been approved in China to treat Pasteasmas diseases in swine and bovine and Mycoplasma infections in chickens. It is not being used in human medicine and it acts very well against Mycoplasma with good results in the performance of birds (Mavromati et al., 2011). Also this drug (and other macrolides) is often used as feed additives for growth promotion as well as therapeutic purposes because they have a wide range antibacterial spectrum. (Scorneaux \& Shryock 1998a and 1998b) observed a marked accumulation of tilmicosin by chicken heterophils, also in monocyte and macrophages, in the presence of bacteria as Pasteurella, rapid release of tilmicosin enhanced intracellular killing by phagocytes. In addition to, this drug is used as antimicrobial and growth promotion, also it has an effect on immunity of bird even in the absence of Pasteurella. So this study must be know the efficacy of tilmicosin on the 
immune response of the bird without presence of Pasteurella and Mycoplasma.

Their use can leave residues in edible products that not only can have direct toxic effects but also may lead to allergic reactions in consumers and to the development of resistant bacteria. On the same side (Thomas, 1994): concluded that if animals or their products (milk-meat-eggs) contain traces of antibiotics when eaten by humans, the effect of these antibiotics residues on the consumer is presumably that of the equivalent dose of antibiotic given directly. (Zhang et al., 2004) stated (HPLC) method for detection tilmicosin residue in broiler chickens after dosing 5-day period in drinking water at 37.5 and $75.0 \mathrm{mg} / 1$ with limits of detection (LOD) were $0.01 \mu \mathrm{g} / \mathrm{g}$ for muscle and $0.025 \mu \mathrm{g} / \mathrm{g}$ for liver and kidney with average recoveries ranged from 80.4 to $88.3 \%$ at $290 \mathrm{~nm}$. Tilmicosin concentrations in liver and kidney were highest on day 3 of medication and on day 5 in muscle, in both low- and high-dose groups, the residue levels in both groups were significantly higher in liver than in kidney or muscle and they recommended 9 days for a minimum withdrawal time for residue levels in muscle, liver, and kidney tissues below the maximum residue level (MRL).

(Emea, 1998): Stated that after oral administration of radiolabelled tilmicosin at doses of $25-450 \mathrm{mg} / 1$ in drinking water for 3-5 days (equal to $4.4-75.1 \mathrm{mg} / \mathrm{kg}$ bw/day) radioactivity was mainly distributed to liver and kidney, and to a lesser extent to muscle and fat, also metabolite identification revealed that the parent compound was the main residue in tissues and the highest total radioactive residues were observed in liver $(6.6 \mathrm{mg} / \mathrm{kg}$ at day 3 , declining to $0.4 \mathrm{mg} / \mathrm{kg}$ at day 14), and to a somewhat lesser extent in kidneys (1.6mg/kg at day 3 , declining to $0.4 \mathrm{mg} / \mathrm{kg}$ at day 14) and relatively low total residues were found in muscle and fat (less than $0.2 \mathrm{mg} / \mathrm{kg}$ at day 3 , declining to below $0.02 \mathrm{mg} / \mathrm{kg}$ at day 14$)$.

\section{MATERIALS and METHODS}

In the present work the kinetic aspects and tissue residues of tilmicosin was studied in broiler chickens.

\section{Drug:-}

Telmicure is a product of Waki pharma (Austria) for EL -Madar company-Mansora, Egypt. tilmicure 250 is a semi synthetic macrolide antibiotics, oral solution, containing Tilmicosin phosphate. Each $1 \mathrm{ml}$ contain Tilmicosin phosphate equivalent to Tilmicosin base $250 \mathrm{mg}$. The drug was given orally in drinking water by the dose of 30 and $60 \mathrm{mg} \mid \mathrm{kg} \mathrm{b.w.}$ for 5 successive days. It has the following Molecular Structural formula:- according to (Zhang et al., 2004)

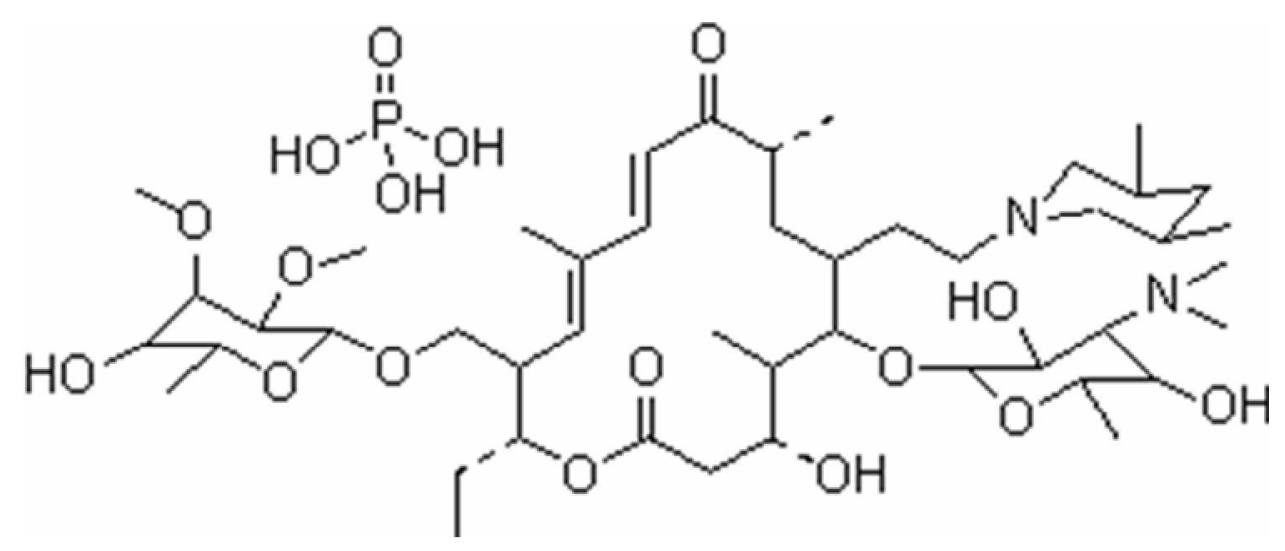

\section{Experimental design}

Chickens:- One hundred one day old broiler chickens were fed balanced rations ad libitum with free access to water. At 3 weeks in this study. The chickens were randomly divided into three groups of 30 chickens each. The first group was control. The second and third group administered tilmicosin in drinking water at concentrations of 30 and $60 \mathrm{mg} / \mathrm{kg}$ bw for 5 days. Six chickens of each group, three males and three females, were slaughtered on days 3, 7, 14 and 21 days after dosing.
Vaccination:- All groups were vaccinated against Newcastle disease with Hitchiner B1 at 7days and LaSota at 21 days of age. Also all groups were vaccinated against Gumboro disease with IBD blen (Ceva) at 13 day of age.

Sampling:- Swabs from the larynx and lung samples were taken from chickens to detect and isolate $P$. multocida. Two blood samples were collected from all groups at the days3,7,14 and 21days post dosing . The $1^{\text {st }}$ blood sample was collected by heart puncture under strict aseptic condition on heparin for 
immunological examination Lymphocytes transformation test (LTT). The $2^{\text {nd }}$ blood sample was collected without anticoagulant for serum separation for measuring Alanine amino transferrase, Aspartate amino transeferrase ALT, AST, creatinine, immunoglobulin fractions and detection of mycoplasma. Samples for detection of antibiotic residues, were collected from muscle of thigh and breast, liver, and kidney of each bird at 3, 7, 14 and 21 day (slaughtering time 42 day old) and stored at $20 \dot{C}$. until they were extracted for quantization by HPLC.

\section{Laboratory examination:- \\ Bacteriological examination:- \\ Culture for detection of pasteurella \\ Isolation:-}

At 3 weeks, before division the chickens into 3 groups. A random samples which included 10 birds were scarified for postmortem and bacteriological examination to detect Pasteurella and to serum plate agglutination test (SPA) to prove that free from Mycoplasma and Pasteurella.

Swabs from the larynx and lung samples were inoculated onto blood agar supplemented with 7\% sheep blood. The plates were incubated under aerobic conditions for $24-48 \mathrm{~h}$ at $37^{\circ} \mathrm{C}$. The agar plates were checked every day for suspected colonies. Identification or confirmation bacterial species was assessed by observation of the colonial morphology and Gram staining results and by biochemical methods. (Carter, G.R. 1984 and Choi, C.C. Chae 2001).

Serum Plate Agglutination (SPA): The chicken were examined for Mycoplasma gallisepticum by serum plate agglutination test (Zelenika et al., 1999), $\operatorname{drop}(0.02 \mathrm{ml})$ from each serum samples was placed on clean dry slide and mixed with one drop (0.02) of stained Mycoplasma gallisepticum standerd antigen was obtained from (Intervet international, B.V.B. Boxmeer, Holland). The two drops were mixed well by a glass rod.

Lymphocytes transformation test (LTT) according to (Nariuchi, H. 1989)

Electrophoresis:- One of the most common means of analyzing proteins by Sodium dodecyl sulphatepolyacrylamide gel electrophoresis(SDS-PAGE) according to (Gombocz, Cortez 1995).

Biochemical analysis:- Aspartate and alanine amino transferase (ALT and AST) activities were determined colorimetrically according to (Reitman and Frankel, 1957). Serum alkaline phosphatase activity was determined according to (Kind and King, 1954). Serum creatinine level according to (Henry, 1974).
Tissue residue examination according to (Zhang et al., 2004):-

Solvents and Reagents: The solvents used were of LC grade, available from commercial sources. Water for HPLC analysis was Milli-Q filtered. Tetrahydrofuran, methanol, and acetonitrile were from Sigma Chemical Co. (St. Louis, MO). Dibutylamine, ammonium acetate, and phosphoric acid (85\%) were purchased from Beijing Chemical Reagent Co. (Beijing, China). Dibutylammonium phosphate (DBAP) solution was prepared by the addition of $168 \mathrm{~mL}$ of dibutylamine to $700 \mathrm{~mL}$ of phosphoric acid. The solution was allowed to cool and was adjusted to $\mathrm{pH} 2.5$ using phosphoric acid, and the volume was made up to $1 \mathrm{~L}$ with water. Monobasic potassium phosphate buffer was prepared by dissolving $13.61 \mathrm{~g}$ of monobasic potassium phosphate in $800 \mathrm{~mL}$ of water, adjusting to $\mathrm{pH} 2.5$ with phosphoric acid, and making up the volume to 1 $\mathrm{L}$ with water. A $0.1 \mathrm{~mol} / \mathrm{L}$ ammonium acetate/methanol/acetonitrile solution was prepared by dissolving $7.71 \mathrm{~g}$ of ammonium acetate in $200 \mathrm{~mL}$ of methanol and $790 \mathrm{~mL}$ of acetonitrile and making up the volume to $1 \mathrm{~L}$ with acetonitrile. The tilmicosin solution (25\%) was produced by Jining Medicine Corp. (Shandong, China). Tilmicosin reference standard was a gift from Lilly Co. Stock solution of 2 $\mathrm{mg} / \mathrm{mL}$ was prepared by dissolving $200 \mathrm{mg}$ of tilmicosin standard in $100 \mathrm{~mL}$ of acetonitrile. The working standard solution of $1 \mathrm{ig} / \mathrm{mL}$ was prepared in acetonitrile.

Apparatus. LC equipment included a Waters 2695 separations module and a Waters 2996 photodiode array detector with an autosampler. The chromatographic column was a reversed-phase column (Extend-C18, Zorbax column, $4.6 \mathrm{~mm}$ i.d. $250 \mathrm{~mm}, 5 \mathrm{im}$, Agilent Co.). Solid-phase extraction (SPE) cartridges (Bond Elut C18, $500 \mathrm{mg} / 6 \mathrm{~mL}$ ) were used to cleann up tissue samples.

Sample Preparation. Chicken tissues (muscle, liver, and kidney) were minced and homogenized in a homogenizer for $2 \mathrm{~min}$. Five grams of homogenate was accurately weighed into a polypropylene centrifuge tube. Ten milliliters of acetonitrile was added and shaken for $20 \mathrm{~min}$. Centrifugation was performed for $10 \mathrm{~min}$ at $3500 \mathrm{rpm}$. The supernatant was removed into a $100-\mathrm{mL}$ polypropylene centrifuge tube, and $5 \mathrm{~mL}$ of monobasic potassium phosphate buffer and $8.0 \mathrm{~mL}$ of acetonitrile were added to the tissue pellet. The mixture was shaken for $20 \mathrm{~min}$ and centrifuged as before. Supernatants were combined, and $40.0 \mathrm{~mL}$ of water was added. The mixture solution was centrifuged at $3500 \mathrm{rpm}$ for $10 \mathrm{~min}$. The supernatant was subjected to SPE cleanup. The SPE cartridge placed into the vacuum manifold system was conditioned with $10 \mathrm{~mL}$ of methanol followed by $10 \mathrm{~mL}$ of water prior to addition of the extracted 
supernatant. After the extract was drained through the cartridge by applying vacuum, the cartridge was washed with $10.0 \mathrm{~mL}$ of water and $10.0 \mathrm{~mL}$ of acetonitrile. The SPE cartridge was dried for at least 3 min. Tilmicosin was eluted from the cartridge with $2.5 \mathrm{~mL}$ of the $0.1 \mathrm{~mol} / \mathrm{L}$ ammonium acetate/methanol/acetonitrile solution. The collected eluate was evaporated to dryness under a nitrogen stream at $30 \square \mathrm{C}$ in a water bath and then reconstituted in $1 \mathrm{~mL}$ of mobile phase. The processed sample solution was filtered with a 0.2-ím syringe filter and injected into the HPLC system.

LC Analysis. The analysis of standards, fortified samples, and incurred samples was performed at room temperature. The mobile phase was prepared by adding $135 \mathrm{~mL}$ of acetonitrile, $55 \mathrm{~mL}$ of tetrahydrofuran, and $25 \mathrm{~mL}$ of $1 \mathrm{M} \mathrm{DBAP}$ to $700 \mathrm{~mL}$ of water and diluting with water to the volume scale of $1000 \mathrm{~mL}$; the flow rate was $1.0 \mathrm{~mL} / \mathrm{min}$, the injection volume was $100 \mathrm{iL}$, and the wavelength was $290 \mathrm{~nm}$.

Calculations: The concentration of tilmicosin in tissue sample can be calculated with the equation

$\operatorname{concn}(\mu g / g)=\frac{(\mathrm{S}-\mathrm{B}) \mathrm{VF}}{\text { KM }}$

where $S$ is the combined area of the cis- and transtilmicosin peaks from the chromatogram, $B$ is the intercept of the standard curve, $K$ is the slope of the standard curve, $M$ is the weight of tissue sample, $V$ is the final volume of sample extract, and $F$ is the dilution factor.

Statistical Analysis: Student's $t$ test was used to test parameters for significant difference between the two dose groups after dosing according to (Sas, 1992).

\section{RESULTS}

Swabs from the larynx and lung samples for detection and isolation of $P$. multocida showed negative results also indole, oxidase and catalase. Glucose, fructose and sucrose fermentation are negative. Ten birds were randomized for Serum plate agglutination (SPA) for Mycoplasma gallisepticum revealed negative results.

Results revealed significant increase in LTT in high dose administration of tilimicosin at the end of experiment (table 1). High dose of tilmicosin ( $\mathrm{H} 1, \mathrm{H} 2$ fig 1) caused decrease albumin levels and $\mathrm{y}$ globulin (fig 1). Serum analysis in this experiment revealed no significant changes in serum creatinine in all period of experiment but ALT showed significant increase in groups treated with low and high dose in all period of experiment in the other hand AST showed non significant changes on group treated with low dose but high dose treated group revealed significant increase in $3^{\text {rd }}$ and $7^{\text {th }}$ day only and return to normal level at 14 days after treatment (table 2). The results of antibiotic tilmicosin residue (table 3) (fig 2) revealed that tilmicosin was absorbed and distributed rapidly in the chicken's tissues, and the liver is the target tissue for tilmicosin residues in broiler chickens where there were the highest residual level in both of low dose $(30 \mu \mathrm{g} / \mathrm{kg}$ b.w.) and high dose $(60 \mu \mathrm{g} / \mathrm{kg}$ b.w.) at $3{ }^{\text {rd }}$ day post treatment which revealed a mean value of $372.5 \pm 1.97 \mu \mathrm{g} / \mathrm{kg}, 574 \pm 5.97 \mu \mathrm{g} / \mathrm{kg}$, respectively. While at 14 day post treatment residue was detected only in the liver and the thigh muscle of the high dose by a mean value of $99.26 \pm 1.46 \mu \mathrm{g} / \mathrm{kg}$ and $15.86 \pm 0.56 \mu \mathrm{g} / \mathrm{kg}$, respectively. On the other side there were significant difference of residual detection between thigh and breast samples which revealed a mean value of $244.18 \pm 5.12 \mu \mathrm{g} / \mathrm{kg}$ and $214.4 \pm$ $1.68 \mu \mathrm{g} / \mathrm{kg}$, respectively at $3^{\text {rd }}$ day post treatment, and decreased significally at $7^{\text {th }}$ day for both thigh and breast samples for high dose which revealed $52.1 \pm$ $1.62 \mu \mathrm{g} / \mathrm{kg}$ and $49.68 \pm 1.93 \mu \mathrm{g} / \mathrm{kg}$, respectively and were detected by a mean value of $15.86 \pm 0.56 \mu \mathrm{g} / \mathrm{kg}$ in the thigh samples of high dose at 14 day post treatment and not detected in the breast samples for both low and high doses at the same time.

While in kidney samples the residual detection at $3^{\text {rd }}$ day post treatment revealed that at high and low doses there were a mean value of $495.08 \pm 5.6 \mu \mathrm{g} / \mathrm{kg}$ and $154.24 \pm 3.1 \mu \mathrm{g} / \mathrm{kg}$, respectively and decreased significantly at day 7 post treatment which revealed a mean value of $116.14 \pm 1.77 \mu \mathrm{g} / \mathrm{kg}$ and $18.61 \pm 1.2$ $\mu \mathrm{g} / \mathrm{kg}$ for high and low doses and not detected at 14 day post treatment.

Table 1: The effect of tilmicosin $(30 \mathrm{mg} / \mathrm{kg}$ and $60 \mathrm{mg} / \mathrm{kg}$ b.wt.) once daily for 5 consecutive days on lymphocyte tansformation test of broiler during experimental period.

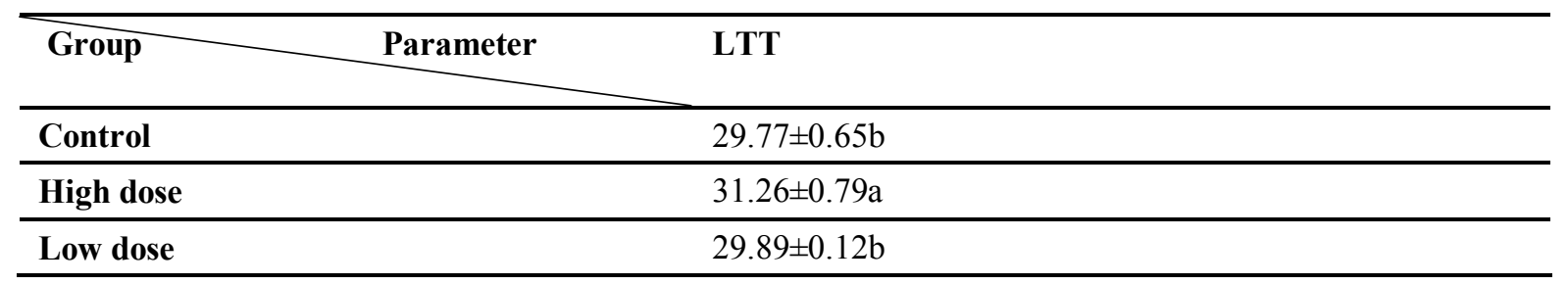

Values are means $\underline{ \pm}$ standard error, Means with different letters at the same raw differ significantly at $(\mathrm{p}<0.05)$. 
Fig. (1): The effect of tilmicosin $(30 \mathrm{mg} / \mathrm{kg}$ and $60 \mathrm{mg} / \mathrm{kg}$ b.wt.) once daily for 5 consecutive days on protein fractions of broiler at the end of experimental period.

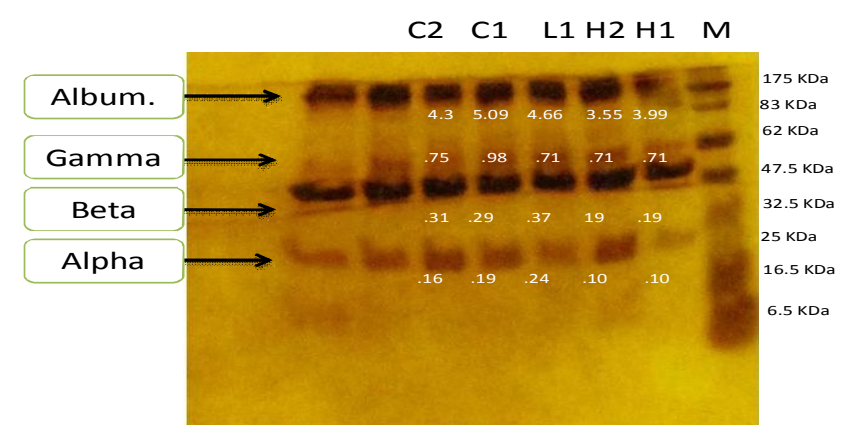

H1and H2 (high dose of telimicosin)

L1 low dose

$\mathrm{C} 1$ and $\mathrm{C} 2$ (control)

$\mathrm{M}$ (marker)

Table 2: The effect of tilmicosin (30 mg/kg and $60 \mathrm{mg} / \mathrm{kg} \mathrm{b.wt}$.) once daily for 5 consecutive days on some kidney and liver functions parameters of broiler during experimental period.

\begin{tabular}{llccc}
\hline Parameters & Period & Control & Low dose & High dose \\
\hline $\begin{array}{l}\text { Creatinine } \\
(\mathbf{m g} / \mathbf{d l})\end{array}$ & $3^{\text {rd }}$ day & $0.86 \pm 0.01^{\mathrm{a}}$ & $0.68 \pm 0.03^{\mathrm{a}}$ & $1.06 \pm 0.45^{\mathrm{a}}$ \\
\cline { 2 - 5 } & $7^{\text {th }}$ day & $0.76 \pm 0.02^{\mathrm{a}}$ & $0.83 \pm 0.04 \mathrm{a}$ & $0.93 \pm 0.41^{\mathrm{a}}$ \\
\cline { 2 - 5 } & $14^{\text {th }}$ day & $0.85 \pm 0.04^{\mathrm{a}}$ & $0.76 \pm 0.02 \mathrm{a}$ & $0.76 \pm 0.34^{\mathrm{a}}$ \\
\hline \multirow{2}{*}{ ALT $(\boldsymbol{\mu} / \mathbf{L})$} & $3^{\text {rd }}$ day & $24.10 \pm 2.66^{\mathrm{b}}$ & $48.0 \pm 5.21^{\mathrm{a}}$ & $46.3 \pm 2.63^{\mathrm{a}}$ \\
\cline { 2 - 5 } & $7^{\text {th }}$ day & $22.83 \pm 1.45^{\mathrm{b}}$ & $47.0 \pm 4.12^{\mathrm{a}}$ & $51.3 \pm 3.64^{\mathrm{a}}$ \\
\cline { 2 - 5 } & $14^{\text {th }}$ day & $22.40 \pm 1.76^{\mathrm{b}}$ & $48.8 \pm 3.87^{\mathrm{a}}$ & $48.7 \pm 2.2^{\mathrm{a}}$ \\
\hline AST $(\boldsymbol{\mu} / \mathbf{L})$ & $3^{\text {rd }}$ day & $82.5 \pm 14.4^{\mathrm{b}}$ & $90.3 \pm 13.1^{\mathrm{b}}$ & $11.0 \pm 4.51^{\mathrm{a}}$ \\
\cline { 2 - 4 } & $7^{\text {th }}$ day & $82.3 \pm 5.21^{\mathrm{b}}$ & $80.5 \pm 5.1^{\mathrm{b}}$ & $113.67 \pm 3.764^{\mathrm{a}}$ \\
\cline { 2 - 4 } & $14^{\text {th }}$ day & $138.3 \pm 11.7^{\mathrm{a}}$ & $114.5 \pm 11.6^{\mathrm{a}}$ & $1066.0 \pm 130.7^{\mathrm{a}}$ \\
\hline ALP $(\boldsymbol{\mu} / \mathbf{L})$ & $3^{\text {rd }}$ day & $351.9 \pm 45.3^{\mathrm{b}}$ & $550.4 \pm 70.3^{\mathrm{b}}$ & $908.33 \pm 76.53^{\mathrm{a}}$ \\
\cline { 2 - 4 } & $7^{\text {th }}$ day & $1033.2 \pm 136.9^{\mathrm{b}}$ & $989.2 \pm 134.9^{\mathrm{b}}$ & $1166.0 \pm 51.9^{\mathrm{a}}$ \\
\cline { 2 - 4 } & $14^{\text {th }}$ day & $788.9 \pm 47.6^{\mathrm{b}}$ & $725.5 \pm 76.7^{\mathrm{b}}$ & $131.05)$.
\end{tabular}

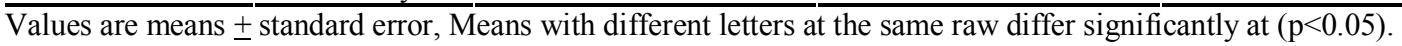

Table 3: The concentration of tilmicosin in tissues of slaughtered chickens at various intervals following the oral administration (30 and $60 \mathrm{mg} / \mathrm{kg}$ b.wt.) once daily for 5 consecutive days.

\begin{tabular}{|c|c|c|c|c|c|c|c|c|c|}
\hline \multirow{3}{*}{ Tissue } & \multirow{3}{*}{ Control } & \multicolumn{8}{|c|}{$\begin{array}{l}\text { The concentration }(\mu \mathrm{g} / \mathrm{kg}) \\
\text { Mean } \pm \text { SE }\end{array}$} \\
\hline & & \multicolumn{2}{|c|}{$3^{\text {rd }}$ day } & \multicolumn{2}{|c|}{$7^{\text {th }}$ day } & \multicolumn{2}{|c|}{$14^{\text {th }}$ day } & \multicolumn{2}{|c|}{21 day } \\
\hline & & $\begin{array}{l}\text { Low } \\
\text { dose }\end{array}$ & $\begin{array}{c}\text { High } \\
\text { dose }\end{array}$ & $\begin{array}{l}\text { Low } \\
\text { dose }\end{array}$ & $\begin{array}{c}\text { High } \\
\text { dose }\end{array}$ & $\begin{array}{l}\text { Low } \\
\text { dose }\end{array}$ & $\begin{array}{c}\text { High } \\
\text { dose }\end{array}$ & $\begin{array}{l}\text { Low } \\
\text { dose }\end{array}$ & High dose \\
\hline Liver & ND & $\begin{array}{c}372.5 \pm \\
1.97 \\
\end{array}$ & $\begin{array}{l}574 \pm \\
5.97 \\
\end{array}$ & $\begin{array}{c}38.1 \pm \\
0.8 \\
\end{array}$ & $\begin{array}{c}155.98 \pm \\
3.4 \\
\end{array}$ & $\mathrm{ND}$ & $\begin{array}{c}99.26 \pm \\
1.46 \\
\end{array}$ & $\mathrm{ND}$ & ND \\
\hline kidney & ND & $\begin{array}{c}154.24 \pm \\
3.1 \\
\end{array}$ & $\begin{array}{c}495.08 \pm \\
5.6 \\
\end{array}$ & $\begin{array}{c}18.61 \pm \\
1.2 \\
\end{array}$ & $\begin{array}{c}116.14 \pm \\
1.77 \\
\end{array}$ & ND & ND & ND & ND \\
\hline Thigh & ND & $\begin{array}{c}70.08 \pm \\
2.37 \\
\end{array}$ & $\begin{array}{c}244.18 \pm \\
5.12 \\
\end{array}$ & $\begin{array}{c}24.12 \pm \\
0.8 \\
\end{array}$ & $\begin{array}{c}52.1 \pm \\
1.62 \\
\end{array}$ & ND & $\begin{array}{c}15.86 \pm \\
0.56 \\
\end{array}$ & ND & ND \\
\hline Breast & ND & $\begin{array}{c}61.78 \pm \\
1.34\end{array}$ & $\begin{array}{c}214.4 \pm \\
1.68\end{array}$ & ND & $\begin{array}{c}49.68 \pm \\
1.93\end{array}$ & ND & ND & ND & ND \\
\hline
\end{tabular}




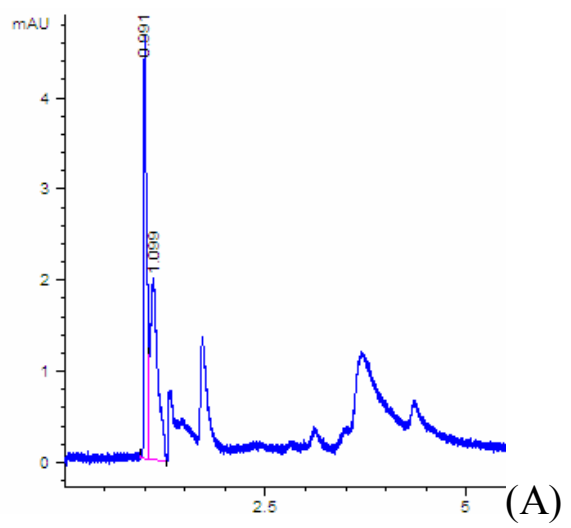

(B)
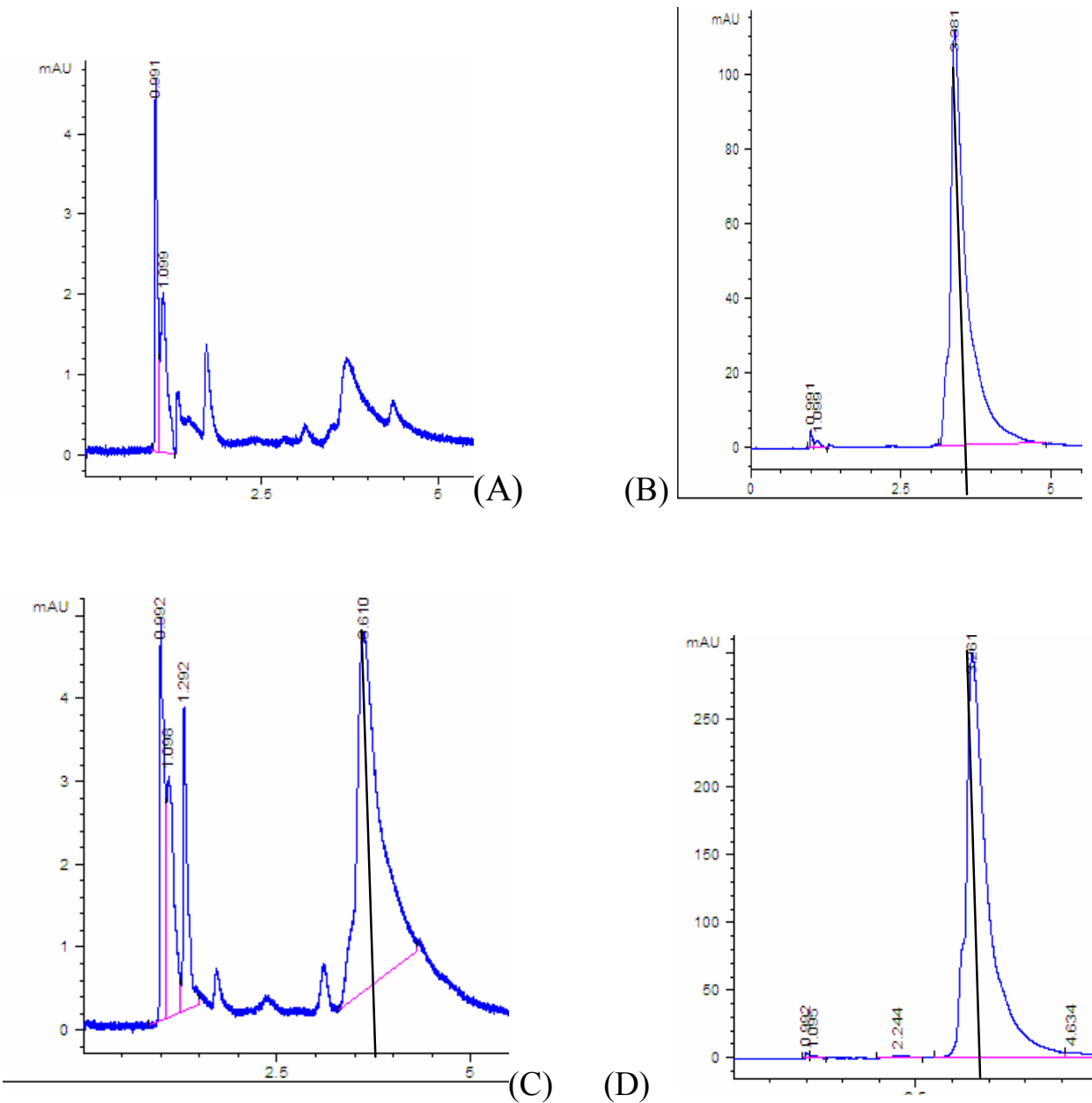

(D)

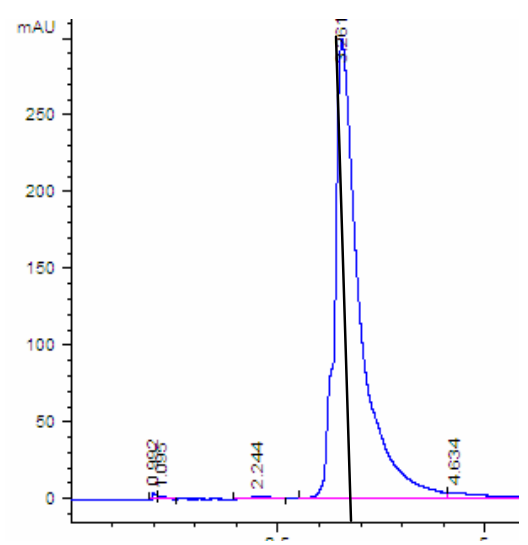

(F)
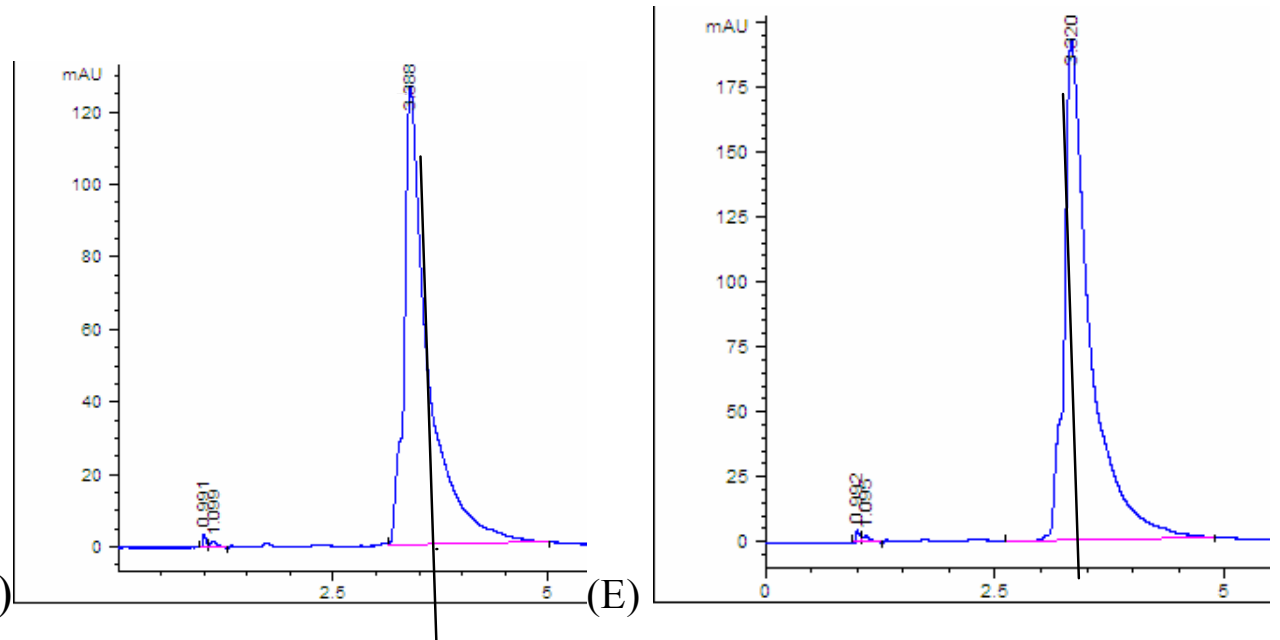

Fig. (2): HPLC chromatograms of (a) Control (b) tilmicosin standard, (C) Spiked sample, (d) liver, (E) kidney, (F) Thigh and breast samples. The vertical line indicates retention time (3.3), with recovery \% 95.2 and wave length $287 \mathrm{~nm}$.

\section{DISCUSSION}

The aim of the current study was to clarify the residual effect of tilmicosin on muscle, liver and kidney tissue as well as its effect on their function and immune response in chickens without infection (Pasteurella and Mycoplasma). Results reveled significant increase in LTT in high dose administration of tilimicosin , this result explained by (Baba, 1998), Macrolide antibiotics are compounds with large lactone rings associated with sugars, generally have a Gram-positive antibacterial spectrum, and act by interfering with bacterial protein synthesis. Tylosin and tilmicosin are macrolides 
antibiotic that are approved for the control of mycoplasmosis in poultry. Several reports have demonstrated that erythromycin increases cellular immune functions in animals; however, few studies have evaluated the immunopotentiating effects of tylosin in domestic animals. The macrophage, a component of the MPS, is part of the first line of defense against infectious organisms in animals. Specific functions of this leukocyte include phagocytosis to engulf and trap organisms, cytokine production to regulate the immune response, and ultimately, pathogen elimination. When macrophages are activated, their functions become enhanced. In fact, reports have shown that macrolide antibiotics can enhance macrophage functions, including bactericidal activity (Fietta et al., 1987). In the early stages of inflammation, biological signals are released at the nidus of infection in order to recruit leukocytes to the site. During this stage, macrophage chemotaxis to the site is required in order for efficient antigen processing or presentation, immune regulation, and pathogen elimination to occur. Tilmicosin had no effect on random migration, but caused a numerical increase in the chemotactic activity of adherent splenocytes from chickens. After administration of tilmicosin, serum total protein level was statistically different from control values. High doses of tilmicosin $(\mathrm{H} 1, \mathrm{H} 2)$ caused a decrease serum protein due to decrease albumin levels and $\mathrm{y}$ globulin and this effect was attributed to tissue damage and edema (Yazare et al., 2001).

The results revealed that ALT showed significant increase in groups treated with low and high dose in all period of experiment. AST showed non significant changes on group treated with low dose but high dose treated group revealed significant increase in $3^{\text {rd }}$ and $7^{\text {th }}$ day only and return to normal level at 14 days after treatment. This increase might be attributed to alteration of membrane permeability or damage of the hepatic cells by direct effect of the drug resulting in escape of these enzymes to the plasma (Coles, 1986). The rise in serum (ALP) activity is concomitantly recorded with liver damage leading to escape of this enzyme into serum in abnormal high concentration (Joan and Pannall, 1981).

The results of antibiotic tilmicosin residue revealed that tilmicosin was absorbed and distributed rapidly in the chicken's tissues, and the liver is the target tissue for tilmicosin residues in broiler chickens where there were the highest residual level in both of low dose $(30 \mu \mathrm{g} / \mathrm{kg}$ b.w.) and high dose $(60 \mu \mathrm{g} / \mathrm{kg}$ b.w.) at $3{ }^{\text {rd }}$ day post treatment which revealed a mean value of $372.5 \pm 1.97 \mu \mathrm{g} / \mathrm{kg}, 574 \pm 5.97 \mu \mathrm{g} / \mathrm{kg}$, respectively. While at 14 day post treatment residue was detected only in the liver of the high dose by a mean value of $99.26 \pm 1.46 \mu \mathrm{g} / \mathrm{kg}$. On the other side there were significant difference of residual detection between thigh and breast samples which revealed a mean value of $244.18 \pm 5.12 \mu \mathrm{g} / \mathrm{kg}$ and $214.4 \pm$ $1.68 \mu \mathrm{g} / \mathrm{kg}$, respectively at $3^{\text {rd }}$ day post treatment, and decreased significally at $7^{\text {th }}$ day for both thigh and breast samples for high dose which revealed $52.1 \pm$ $1.62 \mu \mathrm{g} / \mathrm{kg}$ and $49.68 \pm 1.93 \mu \mathrm{g} / \mathrm{kg}$, respectively and were detected by a mean value of $15.86 \pm 0.56 \mu \mathrm{g} / \mathrm{kg}$ in the thigh samples of high dose at 14 day post treatment and not detected in the breast samples for both low and high doses at the same time. This may be attributed to increase blood supply for thigh than breast, this result under the Maximum residue limits (MRL) in muscle $(50 \mu \mathrm{g} / \mathrm{kg})$ and the recommended withdrawal time is 10 days for tilmicosin. These results agree with (Zhang et al., 2004) and (Emea, 1998).

Measures to monitor a certain number of residues of pharmacological substances in farm animals and in the fresh meat obtained from such animals are described in European Community (EC) Council Directive 96/23/EEC, and the criteria for routine methods to used for this purpose are described in EC Commission Decision 93/256/EEC. Maximum residue limits (MRL) in muscle are $50 \mu \mathrm{g} / \mathrm{kg}$ for tilmicosin, and according to the veterinary drug residue regulations of the Chinese Ministry of Agriculture and European Union. The maximum residue level (MRL) of Tilmicosin in broiler chicken muscle, liver, and kidney are $0.075,1.0$, and $0.25 \mu \mathrm{g} / \mathrm{g}$ respectively.

The results achieved in (table 3) (fig2) revealed that all samples of low dose under examination $(30 \mu \mathrm{g} / \mathrm{g})$ at7 day post treatment had residues $(38.1 \pm 0.8$, $18.61 \pm 1.2, \quad 24.12 \pm 0.8, \mathrm{ND} \mu \mathrm{g} / \mathrm{kg}$ for liver, kidney, thigh and breast, respectively) under the Maximum residue limits (MRL) of $50 \mu \mathrm{g} / \mathrm{kg}$, and detected only at a high dose in the liver at 21 day post treatment a mean value of $99.26 \pm 1.46 \mu \mathrm{g} / \mathrm{kg}$, but in the thigh samples by $15.86 \pm 0.56 \mu \mathrm{g} / \mathrm{kg}$ which under MRL. Furthermore all samples under examination at day 21 post treatment for both high and low doses give negative results for tilmmicosin detection. (Emea, 1998) concluded for the intake of tilmicosin residues of animal origin, all uses of the compound should be taken into account, i.e. the uses in chicken, cattle, sheep and pigs. As tilmicosin is also used in lactating ewes, part of the ADI $(75 \mu \mathrm{g} /$ day; MRL for sheep milk $(50 \mu / \mathrm{L}) \times$ milk consumption $(1.5 \mathrm{~L} / \mathrm{dau})$ is already occupied by intake of residues via milk from sheep. This leaves $165 \mu \mathrm{g}$ per day for residues in liver, kidney, muscle and skin + fat from treated animals. The intake of residues in organs and tissues from chickens is below the remainder of the ADI of $165 \mu \mathrm{g}$ at approximately 14 days after cessation of treatment. 


\section{REFERANCES}

Butcher, G. (2006): Metaphylactic antibiotic use is key to reducing effects of mycoplasma, CRD. Elanco Animal Health Poultry Technical Publication. Volume 2, issue 1.

Carter, G.R. (1984): Pasteurella. Bergeys Manual of Systematic Bacteriology. Vol: I. Williams and Wilkins (Krieg, N. R. and J. G. Holt, Eds), Baltimore. pp. 552-558.

Choi, C. and Chae, C. (2001): Enhanced detection of toxigenic Pasteurella multocida directly from nasal swabs using a nested polymerase chain reaction. Vet. J. 162, 255-258.

Coles, E.H. (1986): "Veterinary Clinical Pathology." 4th Ed.,

European Agency for the Evaluation of Medicinal Products (1998): Committee for veterinary medicinal products tilmicsin (extension to chichen).EMEA/MRL/318/97.

Fietta, A.; Bersani, C.; Santagada, T.; Bertoletti, R. and Gialdioni-Grassi, G. (1987): In vitro activity of macrolides on human phagocytic functions. Chemioterapia 6:52-55.

Gombocz, Cortez (1995): Appl. Theor. Electrophoresis 4, 197-209.

Gaugain, J.M. and Anger, B. (1999): Multireside chromatographic method for the determination of macrolide Residues in muscle by HighPerformance Liquid Chromatgraphy with UV detectiont Journal of AOAC Inernational Vol.82,No.5, 1046-1053.

Henry, R.J. (1974): "Clinical chemistry, principles and techniques." 2nd Ed., Harport and Rowhogerstown, M.D. 862.

Inamoto, T. and Kikuchik, I.J.H. (1994): Antibacterial activity of tilmicosion against Pasteurella multocida and Actionobacillus pleuronumoniae isolated from pneumonic lesions in swine. J. Vet.Med. Sci. , 56, 917921.

Joan, F. and Pannall, P. (1981): "Clinical chemistry in diagnosis and treatment." 3rd Ed., Lioyedluke, London.

Kind P. and King, E. (1954): Colorimetric determination of alkaline phosphatase. J. of clinical pathology.
Mavromati, J.; Mavromati, E. and Gjeta, Z. (2011): The effect of a macrolid antibiotic on the control of Mycoplasmas and production efficiency in broilers. Biotechnology in Animal Husbandry 27(3), p721-731.

Nariuchi, H. (1989): New biochemical practise (12I). Pages 151-152 in Jpn. Soc. Biochem., ed. Tokyo Kagaku doujin Tokyo, Japan. (in Japanese)

Ose, E.E. (1987): In vitro antibacterial properties EL-870, a new semisynthetic macrolide antibiotic. J. Antibiot., 40, 190-194.

Retiman and Frankel, (1957): Colorimetric method for determination of serum transaminase activity. American J. of clinical pathology 28, 65-68.

SAS, Institute (1992): Guide for Personal Computer. SAS Ins. Inc., Carry, NC.

Scorneaux, B. and Shryock, T. (1998a): Intracellular accumulation, subcellular distribution, and efflux of tilmicosin in chicken phagocytes. Poultry Science, 77:1510-1512.

Scorneaux, B. and Shryock, T. (1998b): Intracellular accumulation, subcellular distribution and efflux of tilmicosin in swine phagocytes. J. Vet. Pharm acol. Therap., 21: 257-268.

Stephens, C.P.; Blackall, P.J. and Wadem, L.K. (1993): In vitroantibacterial properties of tilmicosion against Australian isolates of Pasteurella multocida and Actinobacillus pleuropneumoniae from cattle. Aust. Vet. J., 70, 10391-10392.

Thomas, B.B. (1994): Veterinary drug therapy. Lea and Febiger, Awauerly Company.

Yazar, E.; Altunok, V.; Elmas, M.; Tras, B.; BAS, A.L. and Özdemir, $V$. (2001): Effect of tilmicosin on cardiac muscle and serum creatine kinases activities and serum total protein level in healthy male Balb/C mice. Revue Méd. Vét., $152,12,881-883$.

Zelenika, TA.; Savic, V. and Balenoic, M. (1999): Mycoplasmosis in heavy hybird hens in Croatia from 1993-1998.Stocarstvo. 1999.53:6,411-418.

Zhang,Y.; Jiang, H.; Jin, X.; Shen, Z.; Shen, J.; Caixia, Fu,C. and Guo, J. (2004): Residue depletion of tilmicosin in chicken tissues.J. Agric. Food Chem.52,2602-2605. 
قياس بقايا التليمكزين فى العضلات والأعضاء الداخلية فى دجاج التسمين وتأثيره على وظائف الكبد والكلى والمناعة سهام نزييه حموده ، أمل محمود رجب ، سعاد سعد بليح ، أمل فتحى الزغبى

Email: dr-m-wagdy@hotmail.com

أجريت التجربة على عدد 100 كتكوت عمر يوم. تم تقسيمها إلى ثلاث مجموعات متساوية كل مجموعة مكونة من • ·r كتكوت.

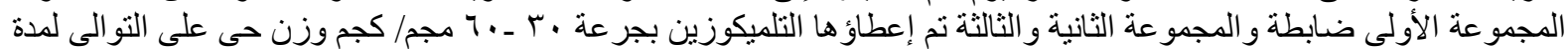

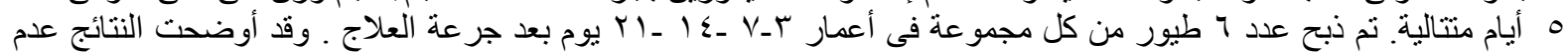

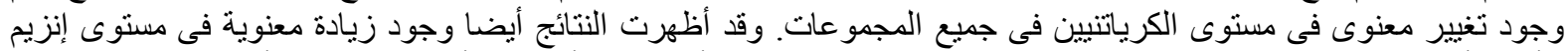

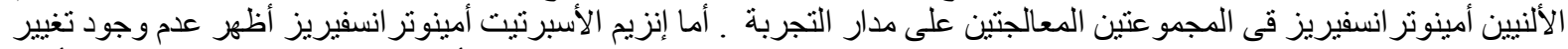

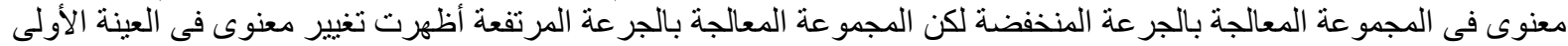

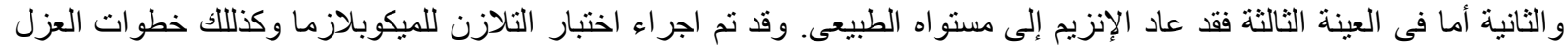

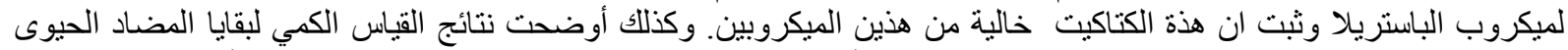

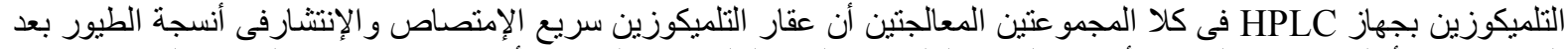

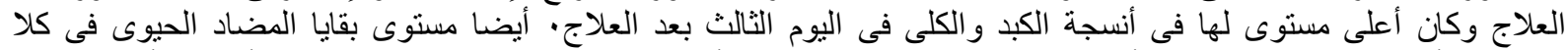

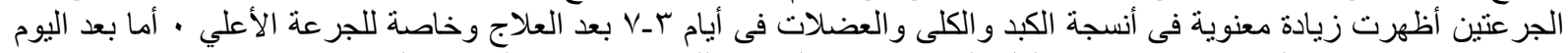

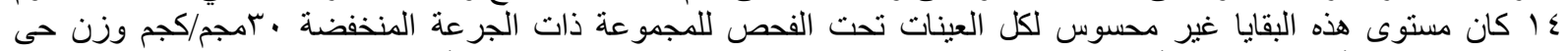

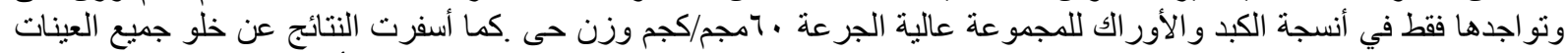

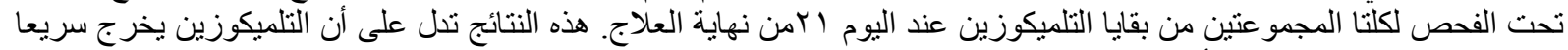
من العضلات وبطىء جدا من أنسجة الكبد. 